\title{
EXPERIMENTAL INVESTIGATION OF THE EFFECT OF MICROWAVE DRYING AND REACTOR TEMPERATURE ON PRODUCT YIELDS FROM PYROLYSIS OF CASSAVA CHAFF
}

\author{
P. O. Okekunle ${ }^{1,}$, S. O. Adetola ${ }^{2}$, O. E. Itabiyii', I. O. Alayande ${ }^{4}$, H. O. Ogundiran ${ }^{5}$ and K. G. Odeh ${ }^{6}$ \\ 1,2,3,4,5,6, DePT OF MECHANICAL ENG'G, LADOKE AKINTOLA UniV. OF TECHNOLOGY, OGBOMOSO, OYo STATE. NIGERIA. \\ E-mail addresses:11pookekunle@lautech.edu.ng,2soadetola@lautech.edu.ng, 3 oeitabiyi@lautech.edu.ng, \\ 4alayandeibraheem13@gmail.com,5 odiranss11@gmail.com,6odehke123@gmail.com
}

\begin{abstract}
Effect of microwave oven drying and reactor temperature has been investigated in this study. Cassava chaff was procured fresh from a cassava flour processing industry in Ogbomoso, Oyo State, South-Western Nigeria. The sample was water washed to remove excess alkali metal present through hydrolysis, sun dried and ground to obtain a uniform size distribution of $2-4 \mathrm{~mm}$. Samples of $50 \mathrm{~g}$ each were microwave dried at five different temperatures $\left(60,75,90,105\right.$ and $\left.120^{\circ} \mathrm{C}\right)$ at a constant time of 30 minutes. The samples were then pyrolyzed in a fixed bed reactor at different temperatures $\left(400,500,600\right.$ and $\left.700^{\circ} \mathrm{C}\right)$ at atmospheric pressure using a residence time of 20 minutes. Results showed that tar yield decreased as both reactor and drying temperatures increased. The yield of char increased as drying temperature increased and decreased as reactor temperature increased except at $700{ }^{\circ} \mathrm{C}$ where possibly repolymerization of light molecular species occurred. The yield of pyrogas was found to increase as both reactor and drying temperatures increased. It was established that both drying and reactor conditions influence products yields distribution during biomass pyrolysis.
\end{abstract}

Keywords: Biomass, cassava chaff, microwave drying, pyrolysis, fixed bed reactor

\section{INTRODUCTION}

Statistical analysis showing the estimated extinction date of fossil fuel of each country has set man into the panic of finding other sources of energy. The world fossil fuel was estimated to be depleted between 2042 and $2050[1,2]$. Renewable energy appears to be a viable way to solve this problem. Available renewable energy resources useful to man include: sunlight, wind, geothermal heat, ocean waves, tides and biomass. Extinction of fossil fuel is one challenge, another is environmental pollution caused by the emission of flue gas from fossil fuel combustion processes [3].

Figure 1 shows the predicted usage of all sources of energy. It shows the rate of fossil fuel usage, which if not monitored may lead to its extinction. Residues from biomass if not properly handled also cost so much in evacuation and recycling. Among the renewable energy sources, biomass has found a wide range of applications due to its availability and high technology used for its conversion into tar, char and pyrogas which are useful for generation of energy and for production of useful chemicals [4].

Several processes have been explored in the conversion of biomass into useful sources of energy $[5,6]$. Pyrolysis, combustion, gasification and liquefaction are the thermochemical routes which are widely used to explore the energy locked up in biomass. Pyrolysis is an important process in biomass thermochemical conversion because it is not just an independent process but also an important phase in combustion and gasification [7]. Determining the temperature at which optimum yields of various species can be obtained will not only help in maximizing the conversion process but will also culminate in design optimization.

Many researchers have oven dried samples at $105^{\circ} \mathrm{C}$ to investigate the effect of moisture content on tar yield $[8,9]$ and found that moisture content less than $10 \%$ in biomass samples is acceptable for pyrolysis to optimize the yield of bio-oil [10, 11]. However, findings on cassava chaff pyrolysis are very scarce. 
Therefore, this work is aimed at investigating the effect of reactor and microwave drying temperatures on products yields (bio-oil, char and pyrogas) from cassava chaff pyrolysis. Effects of particles sizes on product yields during pyrolysis have already been investigated [12]. Application of products yields of biomass pyrolysis can be found in [13].

Cassava chaff is a waste from cassava processing industries, constituting nuisance to the environment. This is because many Nigerians are still using local methods which involve sieving cassava flour to extract the chaffs after crushing and grinding [14]. Nigeria was rated the largest producer of cassava in the world with a total of 52 million tons annually [15].

The method employed in removing cassava chaff shows that $20 \%$ of cassava tuber constitutes cassava chaff [11] which implies that 10.4 million of cassava tubers turn out to be a waste and if not properly managed causes foul smell (air pollution) when left lying on the ground or result in greenhouse effect when sets on fire [16]. Converting this waste to biofuel will save the environment from pollution.

\section{SAMPLE PROCUREMENT AND PROCESSING}

Cassava chaffs used in this research were procured fresh from a cassava processing industry in Ogbomoso, Oyo State, South Western Nigeria. The chaff were ground, sun-dried for 3 days and then dried in a microwave dryer in Chemical Engineering Laboratory, Ladoke Akintola University of Technology, Ogbomoso, Nigeria. The heating chamber is $420 \times 350$ $\times 300 \mathrm{~mm}$ with a fixed laminated tray to carry the sample to be dried. The microwave temperature was monitored using a digital pyrometer scale which can measure temperature up to $1000^{\circ} \mathrm{C}$.

Samples of ground cassava chaff of $50 \mathrm{~g}$ each were dried at five different temperatures $(60,75,90,105$ and $120^{\circ} \mathrm{C}$ ) for 30 minutes. The samples were placed in aluminium crucible $(50 \times 100 \times 40 \mathrm{~mm})$ during drying. The dried samples were allowed to cool down and then reweighed to account for moisture loss using a digital weighing scale of sensitivity $\pm 0.001 \mathrm{~g}$. Moisture loss in the sample at varying drying temperatures was calculated using equation 1. Figure 2 shows the profile of moisture loss at varying drying temperatures. As shown in the figure, the higher the drying temperature, the higher the moisture loss.

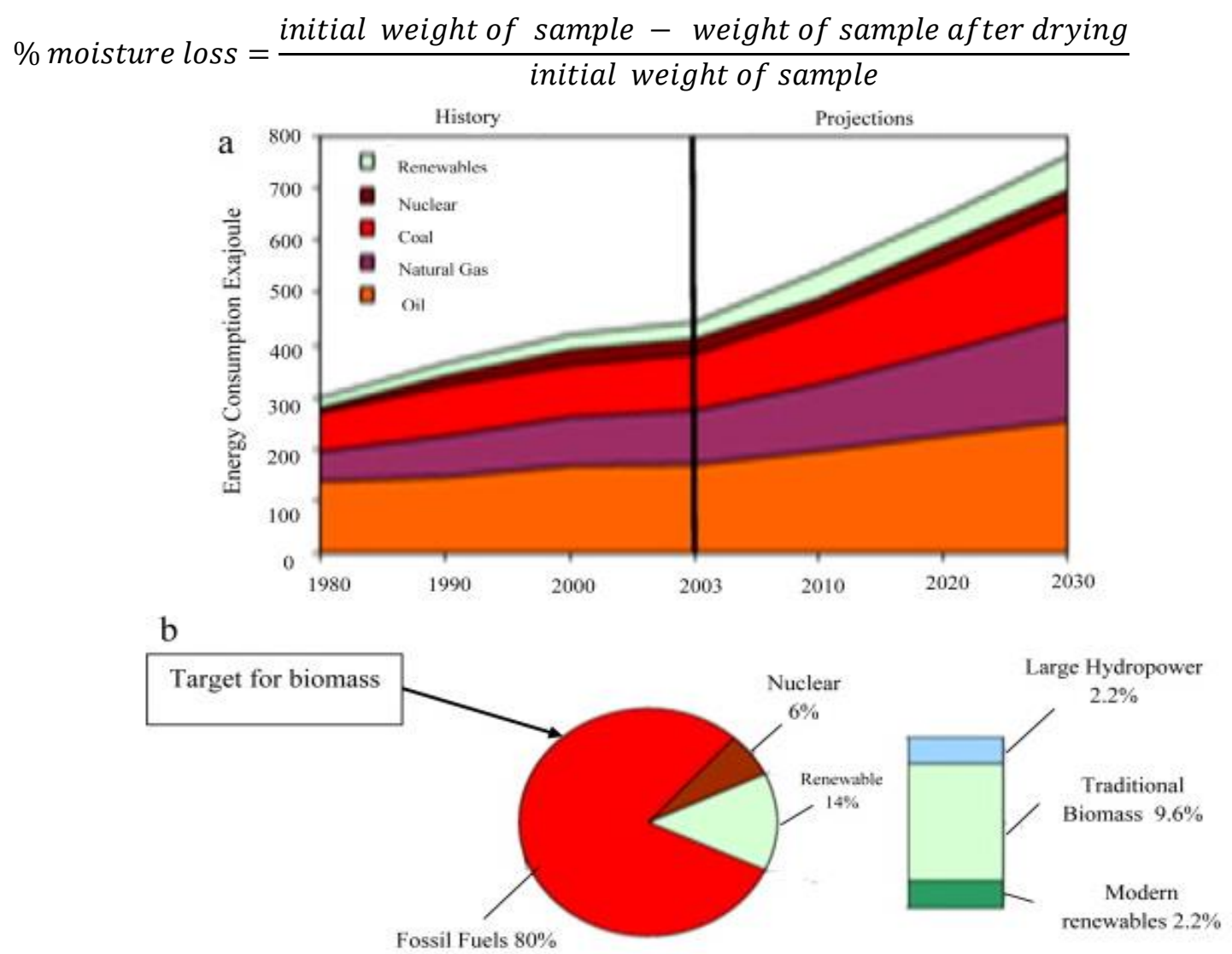

Figure 1: (a) World marketed energy consumption. (b) Different fuel contribution to total world energy consumption, [3] 


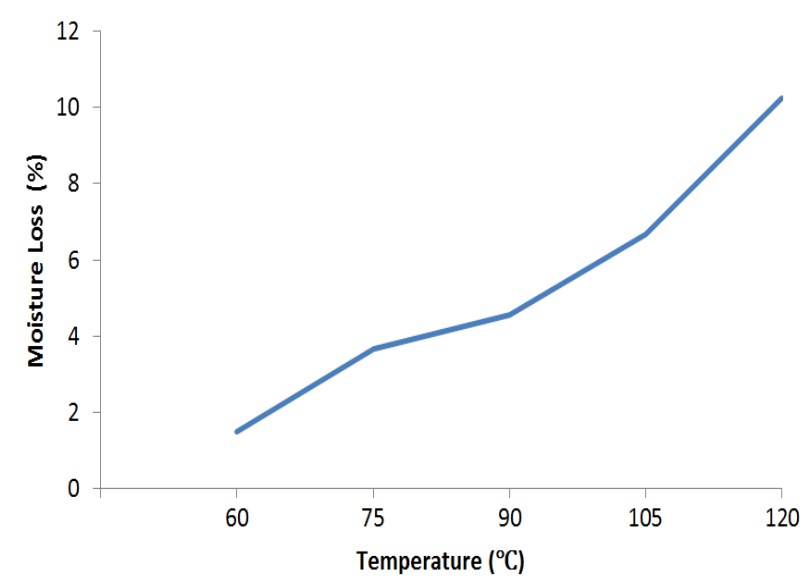

Figure 2: Moisture loss at varying drying temperature.

\section{FIXED BED PYROLYSIS UNIT.}

Figure 3 shows the exploded view of the fixed bed reactor used for the pyrolysis experiment. The reactor comprises of a cylindrical retort with a bottle neck to enhance a firm closure of the lid, products collector pipe, tar collectors and a pyrogas receiver. Carrier gas (Nitrogen) was used to purge the reactor and sweep the volatiles from the reactor. The pipe channeled the volatiles stream into the tar collectors which were immersed in an ice- bath (tar trapper) for condensation of condensable gases and noncondensable gases passed on to the gas collector. Staged tar trappers were employed to ensure that all tarry compounds were condensed in the tar collectors. Pyrolysis of microwave dried samples of $50 \mathrm{~g}$ each was carried out at different temperatures $(400,500$,
600 and $700{ }^{\circ} \mathrm{C}$ ) using a residence time of 20 minutes at atmospheric pressure. The reactor temperature was set at $100{ }^{\circ} \mathrm{C}$ above the desired temperature to compensate for heat loss during insertion of preloaded retort. The reactor was reset to the required temperature immediately after the insertion of retort to maintain constant temperature.

The reactor has a pyrometer of sensitivity $\pm 20^{\circ} \mathrm{C}$. The retort with the sample to be pyrolyzed was inserted into the reactor with its lid firmly secured in place by using the hold down bolts and nuts with gasket as a packing material to prevent product leakage from the retort. The product collectors were weighed to ascertain their initial weight. Residence time of 20 minutes was used by setting the stop watch to 20 minutes count down. The collected tars were measured on weighing balance by subtracting the initial weight of both collectors from their final weight after the experiment. The retort was removed from the reactor immediately after 20 minutes, allowed to cool for 10 minutes, the bolt and nut were loosed and the char was let out from the retort. The char and tar were weighed using a digital weighing balance of sensitivity $\pm 1 \mathrm{~g}$ and the weight was recorded as percentage of initial sample weight. Weight of pyrogas was obtained by subtracting the weight of tar and char from the initial weight of the sample. Products yields were expressed as percentage of initial weight of samples.

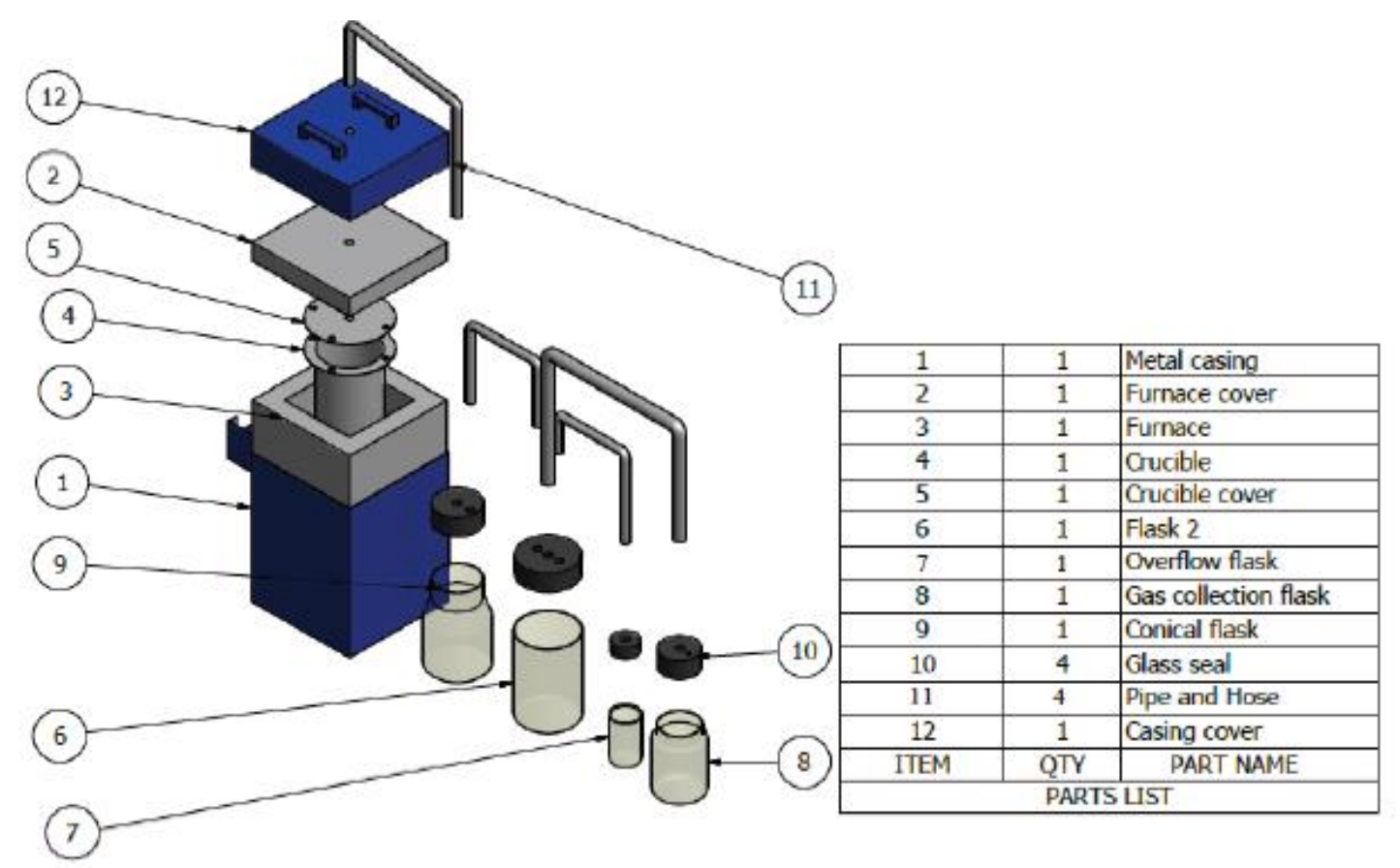

Figure 3: Exploded view of the Pyrolysis Unit. 


\section{RESULTS AND DISCUSSION}

\subsection{Effect of Microwave Drying on Sample Weight.}

Effect of microwave drying on moisture loss of the sample has been shown in Figure 2. As shown in the figure, increase in drying temperature caused increase in moisture loss. This increase in moisture loss with increase in drying temperature was accompanied with decrease in sample weight. Furthermore, there is tendency of partial pyrolysis at high drying temperature since biomass sample temperature would have increased after enormous moisture in the sample has been lost [10].

\subsection{Effect of Drying and Reactor Temperature on Tar Yield.}

Figure 4 shows tar yield profiles at different reactor temperatures $\left(400,500,600\right.$ and $\left.700{ }^{\circ} \mathrm{C}\right)$ and at different drying temperatures $(60,75,90,105$ and $120{ }^{\circ} \mathrm{C}$ ). As seen from Figure 4, increase in drying temperature resulted in decrease in tar yield for all reactor temperatures. Decrease in tar yield from lower to higher drying temperature was due to the fact that traces of moisture present at lower drying temperature condensed once reaching the tar trap immersed in ice- baths during pyrolysis. Hence, the presence of moisture could account for high yield of tar at lower drying temperature. In most pyrolysis experiments, tar is usually trapped with some water molecules $[12,17]$

Effect of reactor temperature on tar yield is also depicted in Figure 4. As shown, increase in reactor temperature caused decrease in tar yield. This result suggested that some tar molecules could have undergone secondary reaction at any temperatures above $400^{\circ} \mathrm{C}$ resulting in more yield of gas $[18,19]$. Tar yield was highest at a temperature of $400^{\circ} \mathrm{C}$ for all drying temperatures. From this result, it is plausible that cassava chaff has a similar percentage of cellulose as oil palm frond [20].

\subsection{Effect of Drying and Reactor Temperature on Char Yield.}

Figure 5 shows char yield profiles at different reactor temperatures $\left(400,500,600\right.$ and $\left.700{ }^{\circ} \mathrm{C}\right)$ and drying temperatures $\left(60,75,90,105\right.$ and $\left.120^{\circ} \mathrm{C}\right)$. As shown in Figure 5, char yield profiles for these conditions do not follow any definite pattern. For instance, at $400{ }^{\circ} \mathrm{C}$ reactor temperature, increase in drying temperature enhanced char yield between $60^{\circ} \mathrm{C}$ and $90^{\circ} \mathrm{C}$.

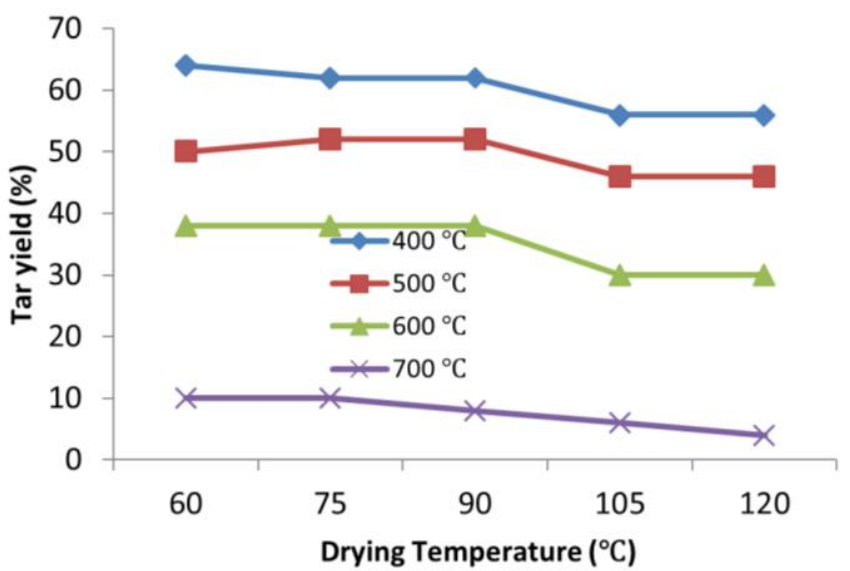

Figure 4: Tar yield at different drying and reactor temperatures

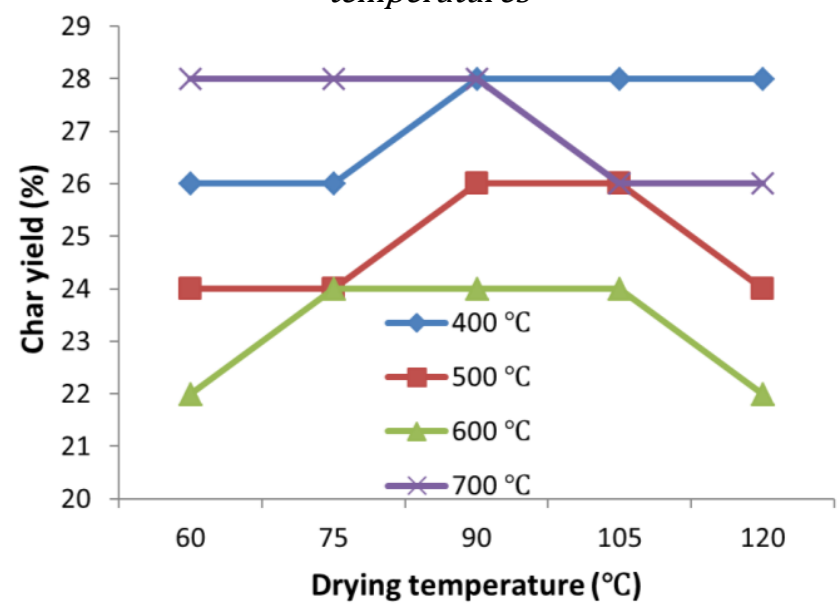

Figure 5: Char yield at different drying and reactor temperatures.

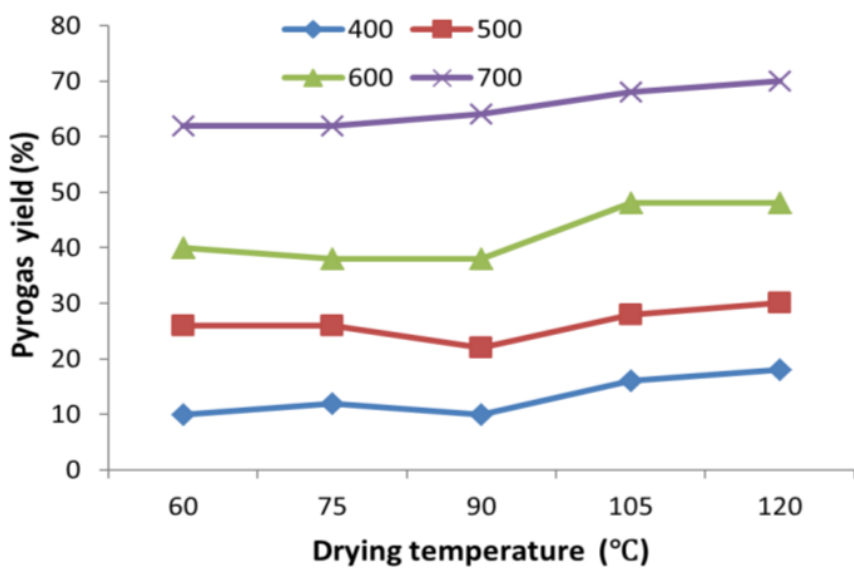

Figure 6: Pyrogas yield at different drying and reactor temperatures

Above $90^{\circ} \mathrm{C}$, increase in drying temperature has no significant effect on char yield at $400{ }^{\circ} \mathrm{C}$ reactor temperature. This may be due to the fact that there is no significant difference in sample moisture content, which could have affected the chemistry secondary reactions, above this temperature. At $500{ }^{\circ} \mathrm{C}$, there was a noticeable increase in char yield from 75 to 90 ${ }^{\circ} \mathrm{C}$ drying temperature. There appears to be no 
significant difference in char yield between 90 and $105{ }^{\circ} \mathrm{C}$, and then a decrease in char yield between 105 and $120{ }^{\circ} \mathrm{C}$. Decrease in char yield at temperatures above $90{ }^{\circ} \mathrm{C}$ may due to the effect of microwave energy obtained by the sample during drying and also due to the increase in surface area [10] which favoured secondary reactions. At $500{ }^{\circ} \mathrm{C}$ reactor temperature, significant secondary reactions could have taken place. At $600{ }^{\circ} \mathrm{C}$ reactor temperature, char yield profile shows some increase from 60 to $75{ }^{\circ} \mathrm{C}$ drying temperature, followed by a horizontal portion (depicting no appreciable change in yield) from 75 to $105{ }^{\circ} \mathrm{C}$, and then a decline between 105 and $120{ }^{\circ} \mathrm{C}$. This profile can also be as a result of variation in moisture content at different drying regimes and the chemistry of associated secondary reactions at such conditions, which are phenomena that are very difficult to explain. At $700{ }^{\circ} \mathrm{C}$ reactor temperature, char yield was highest from 60 to $90{ }^{\circ} \mathrm{C}$ drying temperature and then followed by a continuous decline from 90 to $120^{\circ} \mathrm{C}$. The highest yield of char at reactor temperature of $700{ }^{\circ} \mathrm{C}\left(60,75\right.$ and $\left.90^{\circ} \mathrm{C}\right)$ may be due to the reaction between steam (moisture) and activated carbon resulting in exothermic reaction which may cause high decomposition of tar to yield more char and pyrogas. The continuous decline from 90 to $120{ }^{\circ} \mathrm{C}$ could be traceable to the secondary reactions that would have been highly favoured at such a high reactor temperature. Effect of reactor temperature, as depicted in Figure 5, shows that increase in temperature caused decrease in char yield except at $700^{\circ} \mathrm{C}$ where repolymerization of light molecular species occurred $[17,19]$.

\subsection{Effect of Drying and Reactor Temperature on Pyrogas Yield.}

Figure 6 shows pyrogas yield profile at different reactor temperatures $\left(400,500,600\right.$ and $\left.700{ }^{\circ} \mathrm{C}\right)$ and drying temperatures $\left(60,75,90,105\right.$ and $\left.120^{\circ} \mathrm{C}\right)$. As it can be seen from Figure 6, increase in drying temperature enhanced the yield of pyrogas. This may be due to the fact that the presence of low percentage of moisture at high drying temperature accelerated the rate of particle heating and hence enhanced gas production kinetics during pyrolysis at all reactor temperatures.

From Figure 6, increase in reactor temperature also favoured the yield of pyrogas, the maximum yield being at $700{ }^{\circ} \mathrm{C}$. This was due to decomposition of lignin and increase in the extent of tar cracking [21, 22]. From these observations, increase in both drying and reactor temperature generally favoured the yield of pyrogas except at $90{ }^{\circ} \mathrm{C}$ drying temperature where there was a slight drop at 400 and $500{ }^{\circ} \mathrm{C}$ reactor temperature.

\section{CONCLUSIONS}

Effects of microwave drying and reactor temperatures have been experimentally investigated at atmospheric pressure. Results showed that changes in both drying and reactor temperature have significant effect on biomass products yields. Results showed that there is tendency for secondary reactions to take place at reactor temperatures above $400^{\circ} \mathrm{C}$. This research has shown that cassava chaff which is a byproduct of cassava processing industries can be a good source of bio-fuel for heating purpose and raw materials for chemical processing industries.

\section{REFERENCES}

[1] Walsh, J. H. (2000). Projection of Cumulative World Conventional Oil Production, Remaining Resources and Reserves to 2050. In: The Colorado River Commission of Nevada, "World Fossil Fuel Reserves and Projected Depletion" http://crc.nv.gv/docs/world\%20fossil\%20reserves .pdf, Accessed on June 16, 2016.

[2] Bharat Raj, S. and Onkar, S. (2012). "Global Trends of Fossil Fuel Reserves and Climate Change in the 21st Century" www.intechopen.com/books/ fossilfueland. Accessed on June 16, 2016.

[3] Saidur, R., Abdelaziz, E. A., Demibras, A., Hossain, M. S., Mekhilef, S. "A Review on Biomass as a Fuel for Boiler" Renewable and Sustainable Energy Resources, Vol. 15, 2011, pp 2262-2289.

[4] Quannan, Q. and Mingxin G. "Quality of Poultry LitterDerived Activated Carbon" Bioresources Technology, Vol. 101, Issue 1, 2010, 379-386.

[5] McKendry, P. "Energy Production from Biomass (Part 1): Overview of Biomass", Bioresources Technology, Vol. 83, 2002a, pp 37-46.

[6] Mckendry, P. "Energy Prodution from Biomass (part 2): Conversion Technology", Bioresources Technology, Vol. 83, 2002b, pp 47-54.

[7] Becidan, M., Skreiberg, . and Hustard, J. E. "Experimental Study on Slow Pyrolysis of Thermally Thick Biomass Residues Samples : Intra-Sample Temperature Distribution and Effect of Sample Weight (Scaling Effect)". Fuel, Vol. 86, 2007, pp $2754-2760$.

[8] Samuelson, R., Burvall, J. and Jirjis, R. "Comparison of Different Method for the Determination of moisture Content in Biomass" Biomass and Energy, Vol. 30, 2006, pp. 929-934. 
[9] Suttiback, S., Sriprateep, K. and Pattiya, A. "Production of Bio-oil via Pyrolysis of Cassava Rhizome in a Fluidised-Bed Reactor", Energy Procedia, Vol. 14, 2012, pp $668-673$.

[10] Xianhua, W., Happing, C., Kai, L., Jinga, S. and Hauping, Y. "The Influence of Microwave Drying on Biomass Pyrolysis", International Conference on Bioenergy Outlook, Singapore, April 26-27, 2007.

[11] Ubalua A.O. "Cassava Wastes: Treatments Options and Value Addition Alternatives", African Journal of Biotechnology, Vol. 6, Number 18, 2007, pp 20652073.

[12] Okekunle, P.O., Watanbe, H., Pattanotai, T and Okazaki, K. "Effect of Biomass size and Aspect Ratio on Intra-particle Tar Decomposition during Wood Cylinder Pyrolysis", Journal of Thermal Science and Technology, Vol. 7, Number 1, 2012, pp 1-15.

[13] Czernik, S. and Bridgwater, A. V. (2004). "Overview of Applications of Biomass fast Pyrolysis Oil", Energy and Fuels, Vol. 18, Number 2, 2004, pp 590598.

[14] Aderemi, F. A. and Nworgu, F. C. "Nutritional Status of Cassava Peels and Root Sievate Biodegraded with Aspergillus Niger", American- Eurasian J. Agric. \& Environ. Sci., Vol. 2, Number 3, 2007, pp $308-311$.

[15] Food and Agricultural Organization "Cassava Production", www.fao.org/docrep/007/y5548e/ y5548e07.htm. Accessed on June 16, 2016.

[16] Akponah, E. and Akpomie, 0. 0. "Optimization of Bio-ethanol Production from Cassava Effluent using Saccharomyces Cerevisiae", African Journal of Biotechnology, Vol. 32, 2012, pp 8110 - 8116.
[17] Okekunle, P.O., Watanbe, H., Pattanotai, T. and Okazaki, K. "Numrical and Experimental Investigation of Intra-particle Heat Transfer and Tar Decomposition during Pyrolysis of Wood Biomass" Journal of Thermal Science and Technology, Vol. 6, Number 3, 2011, pp 360-375.

[18] Okekunle, P. O. and Osowade E. A. "Numerical Investigation of the Effect of Reactor Pressure on Biomass Pyrolysis in Thermally Thin Regime" International Journal of Chemical and Process Engineering Research, Vol. 27, 2014. pp 12-22.

[19] Di Blasi C. "Modelling Chemical and Physical Processes of Wood and Biomass Pyolysis" Progress in Energy and Combustion Science, 34, 2008, pp 4790.

[20] Abdul Rahman, A., Abdullah, N. and Sulaiman, F. "Temperature Effect on the Characterization Pyrolysis Product from Oil Palm Fronds" Advances in Energy Engineering, Vol. 2, 2014, pp 14-21.

[21] Zawawi, D., Angzzas, S., Mohd, K., Ashavila Mohd, A., Halizah, A., and Mohd Zainuri, M. "Chemical Composition and Morphological of Cocoa pod Husks and Cassava Peels for Pulp and Paper Production", Australian Journal of Basic and Applied Sciences, Vol. 7, Number 9, 2013, pp $406-411$.

[22] Okekunle, P. O., Osowade, E. A. and Oyekale, J. O. "Numerical Investigation of the Combined Impact of Reactor Pressure and Heating Rate on the Evolution and Yield of Biomass Pyrolysis Product in Thermally Thin Regime", Journal of Energy Technologies and Policies, Vol. 5, Number 3, 2015, pp 93- 106. 